\section{Open University Graduates}

From all appearances the Open University seems to have weathered the storms of the first three years of its existence and the awarding of the university's first degrees recently set the seal on the formative years. But in spite of this first outward sign of success the critics of the university have not been silent and they have taken this opportunity to analyse the development of the university since the concept was first mooted and, not surprisingly, have come up with the conclusion that the way the university now operates does not completely conform with the much publicized principle enunciated in the mid1960s that the Open University would educate the masses through the medium of radio and television.

It is not clear whether the label "a glorified correspondence college" which has been attached to the university recently, was issued in sorrow or in glee but it is misleading to think that the Open University can be compared with courses run by local education authorities. It must be admitted, however, that the greater part of the instruction of the university is provided in the form of course units which must be read weekly but these are supplemented and complemented by tutorial and counselling evenings as well as by radio and television programmes which taken together with the annual residential summer school build up into a unified structure which makes the Open University teaching system unique. With hind sight it seems inevitable that the university has had to rely on correspondence courses to provide the bulk of the instruction but the high quality of these courses has, in no small part, helped to put the emphasis where it lies today. But with this record of success behind it, the university, now considering its plan for the next three years, must decide whether the overall balance of teaching by correspondence, instruction through tutorials and enlightenment through the media is the most efficient and proper way to educate its students.

But what will the future bring? The emphasis so far has been very much on the undergraduate courses but some post experience courses have made their appearances in the last year. Will the university make an effort to remain primarily a vehicle for providing a second chance for students who for one reason or another did not progress to university (or some other degree granting institution) at the age of eighteen or will it concentrate more and more on providing refresher courses and other courses for already qualified people?

It is, of course, possible that in the not too distant future the university will find itself being forced to change its courses simply because of the number of applications it receives for particular types of study but should it in such circumstances bow to these pressures or should it make all efforts to go out and search for the type of students it wants? One of the admitted deficiencies of the present student body is that it contains too few students who are employed in jobs which can be classed as manual, or to put it bluntly the university is not succeeding as well as it should in attracting students from the working classes. Certainly $4 \%$ of the present students are working class, a figure which compares most favourably with the number of children of working class parents studying at conventional universities in Britain. But if the university is to make the mark it should on British society then the difficult task of increasing this percentage must be attacked vigorously. This is not easy, for the motivation for non-manual workers to obtain degrees is higher than for manual workers.

In the short term, however, the university should be thinking of how best to cater for the needs of its present student body. The great majority of these who started with no formal qualifications are completing one course a year which means that they are now after three years half way towards their coveted degrees. Many of these students who are sacrificing a great deal of their family lives would welcome the opportunity to accelerate their progress. Would it not be possible to arrange a system by means of which students after they had demonstrated their ability by successfully studying for three years could then spend the best part of a year at a more conventional university obtaining the remaining necessary credits towards their degrees? Whichever way the Open University turns in future it must make closer ties with conventional universities. The drive and initiative which got the university off the ground is still present but it now needs to be channelled towards different goals.

\section{Years Ago}

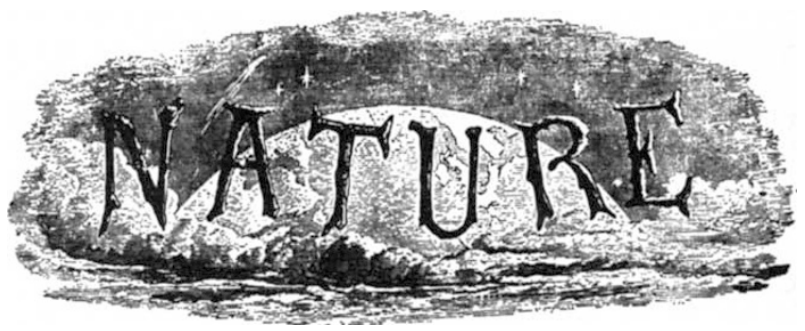

AFreR the alarming rumours that have recently fusund their way into the newspapers, it is a great relief to receive what appears to be really authentic news of the safety of Sir Samual and Lady Baker. It appears, from the messaye received by the Ditily 'lele; raph, that they arrived at Krarto.m on the 29tin of June. It is stated that the party had been as fiar south as a place called Mosindi, near the chief village of Kamrasi, the King of Unyoro, which would be in about $1^{\circ} 45^{\prime} \mathrm{N}$. Jat., and about 80 miles to the east of the shores of the Albart Nyanza. Itere Sir Samuel is said to have been altacked by a chief named Kabriki, and, on his retreat, by a party of slave hunters. He seems to have established another Egyptian station at a piace called Fatiko, somewhere to the south of Gondokoro. The stocy about the Albert Nyanz 1 and Lake Tanganyika being one, which forms part of the news pablished by the Daily Telegrapih, is certainly very startling news, and must at present be received with great caution, though the Telegrapiz correspondent declares he received it direct from the lips of the Emancipator of Central Africa himself.

From Nature, 8, 209, July 10, 1873. 